\title{
Sudan Studies Association
}

The second annual conference of the Sudan Studies Association will be held at Howard University's Armour J. Blackburn University Center during the weekend of 25-27 March 1983. The conference is expected to attract a wide range of scholars, diplomats and people of Sudanese origin from throughout the world. The theme of the conference is The Sudan: perspectives on diversity and change. Arrangements for housing accommodation should be made through the Howard Inn, 2225 Georgia Avenue N.W., Washington, DC 20001; telephone (202) 462-5400. All prospective papers, proposals, suggestions and enquiries should be addressed c/o Ms Joanne Zellers, PO box 3385, Falls Church, Virginia 22043. The deadline for submission of abstracts is 15 December 1982.

\section{Marketing boards}

The African Studies Centre in Leiden intends to organise an international seminar on 'Marketing Boards in Tropical Africa' in autumn 1983. Further particulars and registration forms may be obtained from $\mathrm{Dr} H$. L. van der Laan, African Studies Centre, PO box 9507, 2300 RA Leiden, Netherlands.

\section{Yves Personne}

As we go to press we are saddened to learn of the death of Yves Personne. A formal obituary notice will appear in a forthcoming issue.

\section{Suite de p. 43}

au seizième siècle), et durant la conquête britannique en 1896. La plupart de l'article est 'conjectural', au sens très précis de 'deviner' ce qui vraiment eu lieu; tout cela, l'auteur espère, est fondé sur l'appréciation réaliste de la dynamique de l'histoire Asante, et la substance de l'article cherche à contrebalancer le positivisme si prédominant en historiographie tant africaine que plus spécialement Asante. L'auteur ne cherche pas à s'excuser de ses 'hypothèses', mais, au contraire, suggère que cette sorte d'approche - sensiblement suggestive, et à la fois bien informée-pourrait être une direction nouvelle à l'égard des études historiques africaines. 